\title{
The use of treated effluent for agricultural irrigation: current status in the Bottelary catchment (South Africa)
}

\author{
N. Z. Jovanovic \\ CSIR, Natural Resources and Environment, Stellenbosch, South Africa
}

\begin{abstract}
The Bottelary river is located in a Mediterranean climate region (Western Cape, South Africa), where the agricultural sector plays an important role in the economy. During the dry summer season, there is not enough precipitation to meet the agricultural irrigation requirements. The objectives of this study were to investigate effluent quality, farmers' perception and the potential extent of irrigation of crops with treated effluent from the Scottsdene Wastewater Treatment Works (WWTW). The research made use of historic effluent quality data (from 2001 to 2004) to determine the suitability of this water for irrigation, a questionnaire to determine the farmers' perception, and the SAPWAT model for crop water requirements to determine the potential area that could be irrigated with treated effluent. The effluent quality analysis indicated that this water generally complied with international guidelines and national standards, and it is suitable for irrigation of most crops. The results of the questionnaire indicated that farmers are generally willing to use treated wastewater for irrigation, provided that infrastructure for wastewater supply is accessible and acceptable effluent quality is ensured by the WWTW to minimize possible negative impacts on health, crops, soils and waters. Estimation of crop water requirements indicated that treated effluent could become an additional water resource in the region, in particular during the dry summer months. In order to implement the use of treated effluent on a large scale, it is necessary to establish the required infrastructure, monitoring systems to control negative impacts on human health, crops, soils, surface and groundwaters, as well as extended public participation.

Keywords: Bottelary river, crop water requirements, effluent reuse, farmers' perception, irrigation, SAPWAT, Scottsdene, wastewater treatment works, water quality.
\end{abstract}




\section{Introduction}

Reuse of wastewater for irrigation is a practice that is already applied around the world for many years. Pescod [1] gave an overview of wastewater characteristics and quality parameters for reuse in agriculture and aquaculture, aquifer recharge, treatment technologies, irrigation management as well as policy issues. The advantages of reusing wastewater for irrigation were listed in several publications [2-4] (e.g. reduced demand on potable sources of fresh water; wastewater is a large and reliable water source rich in nutrients; soils and vegetation act as bio-filters with consequent lower treatment requirements and limited impact on the aquatic environment and downstream users; the system requires relatively low capital, operation and maintenance costs). The main disadvantage of this practice is the unknown impact of wastewater on crops and vegetation, soils, surface and groundwaters, as well as human and animal health, in particular in the long term. The main water quality issues were singled out to be pathogens, inorganic salts, heavy metals, pharmaceuticals, carcinogenic substances and endocrine disruptors [4]. The reuse of sewage water for irrigation is also constrained by management and socio-economic factors, like for example the availability of irrigable land in the vicinity of wastewater treatment plants, psychological repugnance and religion, distance to potable water supply wells, community size and relative location to other communities for trade-off opportunities, clarity on ownership of wastewater, and difficulty in quantifying opportunity costs of irrigation with wastewater. The seasonal character of wastewater reuse and peak period of demand may also result in overloading wastewater treatment plants during the rainy season and shortage of water supply during the dry periods of high water requirements [2].

Due to the population growth and extensive development in the Western Cape (South Africa), in particular in the Cape Flats in the vicinity of Cape Town, new and alternative strategies are required in order to manage treated sewage water. The total water supply within the Cape Metropolitan Area (CMA) is about 800 $\mathrm{ML} \mathrm{d}^{-1}$ and the water is used by different sectors. There are twenty wastewater treatment works (WWTW) and three sea outfalls in the CMA. The total volume of treated wastewater is $539 \mathrm{ML} \mathrm{d}^{-1}$, but only $9 \%$ is being reused for summer irrigation $(6 \%)$, industrial processing $(0.6 \%-1.5 \%)$ and aquifer recharge $(1.7 \%-2.5 \%)$. The Western Cape was subject to serious water shortages due to below-average rainfall in the past years (in particular 2003 and 2004) that lead to necessary water restrictions being imposed on the population. If the treated effluent reuse can be extended to a wider area, portion of the fresh water supply will be freed for high value uses in domestic supply, commerce and industry.

In this study, an assessment of the current status of irrigation with treated effluent was carried out in the Bottelary catchment. The Bottelary river is a tributary of the Kuils river, it is $14 \mathrm{~km}$ long and its catchment covers an area of about $80 \mathrm{~km}^{2}$. The catchment is located in the peri-urban area of the Cape Flats and it is, in many ways, representative of the whole CMA (fig. 1). Agriculture, predominantly winery and vegetable farming, is the major activity. The Scottsdene WWTW are located in this area. In summer, the effluent forms the 
entire water flow of the Bottelary river. The treated effluent is therefore a potential water resource for agricultural irrigation. The reuse of treated effluent provides an opportunity for the local farmers to sustain their livelihood especially during the dry summer season, and irrigation is already taking place on some vegetable farms adjacent to the discharge canal.

The specific objectives of the study were: i) to assess the quality of the effluent from Scottsdene WWTW and its suitability for agricultural irrigation in the Bottelary river catchment; ii) to investigate the farmers' perception of using treated effluent for agricultural irrigation; and iii) to assess the potential areas that could be irrigated with the effluent from Scottsdene WWTW.

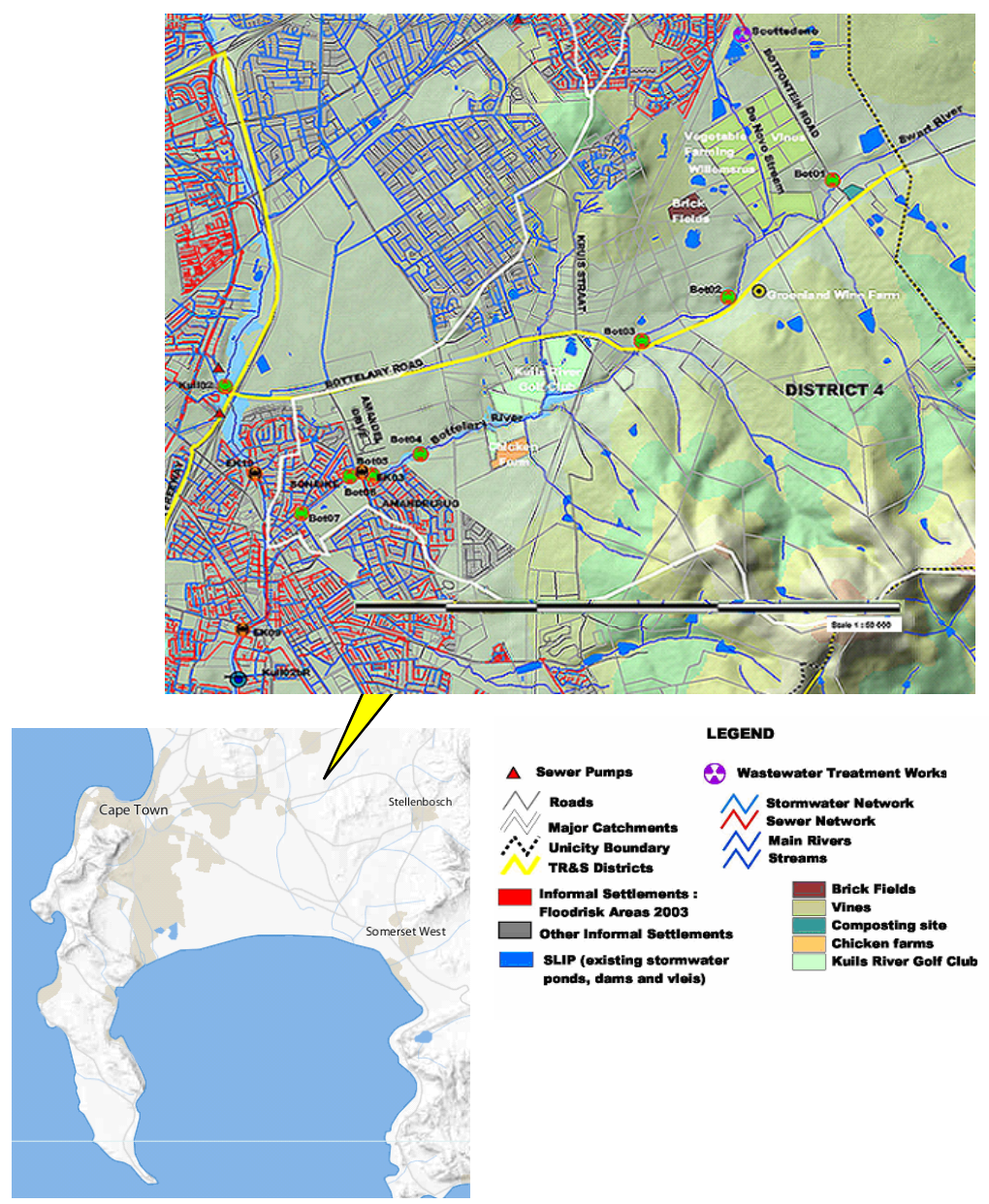

Figure 1: Location of the study area downstream of the Scottsdene wastewater treatment works and in relation to the Cape Peninsula. 


\section{Material and methods}

The study area is located in a Mediterranean climate region, with hot dry summers and cool wet winters. The mean annual precipitation is approximately $600 \mathrm{~mm}$, with $80 \%$ of the annual rain falling in the winter season between March and September. The upper streams of the Kuils and Bottelary rivers are located on the Malmesbury group, which includes quartzites, phyllite, greywacke and shales of Pre-cambrian age. The rocks are thinly covered by recently deposited turf and loam. These geological features result in high surface runoff and small subsurface flow. The sandy marine deposits downstream of the confluence of the two rivers result in little surface runoff.

The Scottsdene WWTW employs an activated sludge process to treat wastewater, which comes mainly from domestic water users. The process makes use of a separator for grit removal and a series of aerobic, anoxic, sedimentation and maturation ponds. Wastewater is chlorinated before being discharged to the receiving water body, whilst the sludge is dried in drying beds. No industrial effluent is fed into the sewage system. Historic data of effluent quality were used to determine the suitability of the treated effluent for reuse in agricultural irrigation. The effluent quality data were obtained from the Scientific Services Department of the City of Cape Town, which monitored effluent quality of Scottsdene WWTW weekly from January 2001 to November 2004. In total, 201 observations were available for statistical analysis. The water quality variables were total suspended solids (TSS), chemical oxygen demand (COD), ammonia $\left(\mathrm{NH}_{3}\right)$, nitrate $\left(\mathrm{NO}_{3}\right)$, orthophosphorus $\left(\mathrm{PO}_{4}\right)$, fecal coliform as well as flow rate. Seasonal trends, averages, medians, standard deviations, minimum and maximum values were determined for each variable. Regression analyses were done for each pair of water quality variables. Averages of electrical conductivity (EC) and $\mathrm{pH}$ were calculated for the periods when these variables were measured (from July 2002 to June 2004). Water quality was evaluated based on the guidelines of the United States Environmental Protection Agency (USEPA) [5], the World Health Organization (WHO) [6] as well as South African standards of Regulation No. 991 - Requirements for the Purification of Wastewater or Effluent (Government Gazette issued on 18 May 1984) - revised in 2005.

The farmers' perception on effluent irrigation was investigated through personally administered questionnaires. A list of nine farms was compiled based on the cadastral map provided by the Oostenberg Municipality and the location of the Scottsdene WWTW. The questionnaire was first distributed to these nine farms, most of which were vineyard farms. In a second round, the questionnaire was distributed to seven additional vegetable farms in the same area. The questionnaire included 26 questions split into four categories (socio-economic factors, production factors, behavioral factors and perception of wastewater irrigation). Most questions were organized into multiple-choice format in order to facilitate data processing and interpretation. Eleven questionnaires were returned out of 16 that were distributed. This small population sample allowed to gain useful information, although it wasn't suitable for statistical inferences. 
The potential area that could be irrigated with effluent from the Scottsdene WWTW was calculated using data of cropping systems obtained from the questionnaires, effluent flow and irrigation requirements estimated with the SAPWAT computer model v. 2.6.0 [7]. SAPWAT is computer software for estimation of crop water requirements and irrigation planning. It includes databases of South African climates and crops. In this study, climate data were selected from the SAPWAT database (Klein Bottelary weather station). The software estimates crop factors from crop type, geographical region (winter rainfall), planting dates and crop canopy cover at full growth. Other input data are type of irrigation system and efficiency, frequency of wetting and wetting area. The SAPWAT model outputs monthly crop evapotranspiration, rainfall, effective rainfall and irrigation water requirements. Irrigation water requirements are calculated as the difference between crop evapotranspiration and effective rainfall. It was assumed that storage capacity is available to store the effluent during periods of low crop water requirements in winter.

\section{Results}

Table 1 summarizes the average, standard deviation, maximum and minimum values of effluent flow and quality variables during the study period. The high standard deviations indicated that values fluctuated widely. The average treating capacity was $7.8 \mathrm{ML} \mathrm{d}^{-1}$, which indicated that the Scottsdene WWTW worked beyond its capacity of $7.5 \mathrm{ML} \mathrm{d}^{-1}$. The peak flow was due to stormwater inflow

Table 1: $\quad$ Statistical data of effluent flow and quality (from January 2001 to November 2004) for the Scottsdene wastewater treatment works, and water quality guidelines.

\begin{tabular}{|l|c|c|c|c|c|c|c|}
\hline Variable & $\begin{array}{c}\text { Flow } \\
(\mathrm{ML} / \mathrm{d})\end{array}$ & $\begin{array}{c}\mathrm{TSS} \\
(\mathrm{mg} / \mathrm{L})\end{array}$ & $\begin{array}{c}\mathrm{COD} \\
(\mathrm{mg} / \mathrm{L})\end{array}$ & $\begin{array}{c}\mathrm{NH}_{3} \\
(\mathrm{mgN} / \mathrm{L})\end{array}$ & $\begin{array}{c}\mathrm{NO}_{3} \\
(\mathrm{mgN} / \mathrm{L})\end{array}$ & $\begin{array}{c}\mathrm{PO}_{4} \\
(\mathrm{mgP} / \mathrm{L})\end{array}$ & $\begin{array}{c}\text { Fecal } \\
\text { coliform } \\
(\text { counts/ } \\
100 \mathrm{~mL})\end{array}$ \\
\hline Average & 7.8 & 13.4 & 51.2 & 7.8 & 2.0 & 7.2 & 33,372 \\
\hline Median & 7.5 & 10.0 & 45.0 & 7.1 & 1.0 & 7.0 & 450 \\
\hline $\begin{array}{l}\text { Standard } \\
\text { Deviation }\end{array}$ & 2.3 & 14.5 & 24.4 & 4.5 & 2.5 & 2.0 & 74,492 \\
\hline Maximum & 17.1 & 190.0 & 279.0 & 24.0 & 14.0 & 15.0 & 510,000 \\
\hline Minimum & 2.6 & 1.0 & 22.0 & 0.9 & 0.0 & 1.9 & 5 \\
\hline USEPA [5] & - & $\begin{array}{c}\leq 2 \mathrm{NTU} \\
\leq 30^{\mathrm{c}}\end{array}$ & $\begin{array}{c}\mathrm{a} \text { b } \\
\leq 30 \mathrm{BOD}^{\mathrm{b}, \mathrm{d}}\end{array}$ & - & - & - & $\begin{array}{c}\mathrm{None}^{\mathrm{b}} \\
\leq 200^{\mathrm{c}}\end{array}$ \\
\hline WHO [6] & - & $<50^{\mathrm{e}}$ & - & $\mathrm{TN} \mathrm{N}^{\mathrm{f}}<5 \mathrm{mg} / \mathrm{L}^{\mathrm{e}}$ & - & $\leq 10^{6} \mathrm{DALY}^{\mathrm{g}}$ \\
\hline S.A. standards & - & 18 & 65 & 3.0 & 15 & 1.0 & $1,000^{\mathrm{h}}$ \\
\hline
\end{tabular}

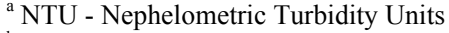

${ }^{\mathrm{b}}$ For food crops not commercially processed

${ }^{\mathrm{c}}$ For food crops commercially processed and non-food crops

${ }^{\mathrm{d}}$ BOD - Biochemical Oxygen Demand

${ }^{\mathrm{e}}$ No restriction on use [8]

${ }^{\mathrm{f}} \mathrm{TN}-$ Total Nitrogen

${ }^{g}$ DALY - Disability Adjusted Life Years per person per year as health-based target

${ }^{\mathrm{h}}$ Proposed standard to be implemented in 2010 is 100 counts $/ 100 \mathrm{~mL}$
} 
in the winter season. Generally, the flow in summer was lower because of lack of precipitation, but the seasonal trends were weak.

Values of TSS generally complied with international guidelines and local standards. In terms of the peak value, the possible reason could have been either poor water sampling or the breaking up of the sludge in the maturation pond. Concerning COD, the peak value $(279 \mathrm{mg} / \mathrm{L})$ appeared on 15 October 2003 , which was exactly on the same day as the peak value of TSS. Values of COD were generally higher in summer due to the dilution effect of urban stormwater in winter, but the average and median were lower than the local standard of $65 \mathrm{mg} / \mathrm{L}$. There is no generalized correlation between COD and BOD for comparison with international guidelines. Organic speciation can also pose a risk to human health. Maximum permissible health-related pollutant concentrations of specific organic compounds in receiving soils were given by WHO [6]. Weak seasonal trends were observed for $\mathrm{NH}_{3}, \mathrm{NO}_{3}$ and ortho- $\mathrm{PO}_{4}$ concentrations. Concentrations of $\mathrm{NH}_{3}$ were generally higher than those given by local standards, whilst $\mathrm{NO}_{3}$ concentration complied with local guidelines. Concentration of ortho- $\mathrm{PO}_{4}$ in treated effluent did not comply with the local standard. However, both elevated $\mathrm{N}$ and $\mathrm{P}$ in irrigation water could be beneficial to crops at certain growth stages. Most of the fecal coliform data complied with local standards as the average exceeded the standard value, but the median did not (table 1). This was due to a period from October 2003 to October 2004, when high fecal coliform levels were recorded because the chlorine tank at the Scottsdene WWTW was not operating.

Values of $\mathrm{pH}$ during the period of measurement ranged from 6.9 to 8.7 (average 7.4), whilst EC varied between 40.5 and $60.5 \mathrm{mS} / \mathrm{m}$ (average $50 \mathrm{mS} / \mathrm{m}$ ). Local effluent standards indicate an optimal $\mathrm{pH}$ range of 5.5-9.5 and no requirements for EC. South African Water Quality Guidelines [9] provide a target $\mathrm{EC}$ value of $40 \mathrm{mS} / \mathrm{m}$ for agricultural use. If the range is between 40 and $90 \mathrm{mS} / \mathrm{m}, 5 \%$ yield losses can be expected for salt sensitive crops [9].

The squared coefficient $\mathrm{R}^{2}$ between TSS and COD was found to be relatively high (fig. 2). This may indicate that suspended solids in water adsorb organic compounds and transport them. The $\mathrm{R}^{2}$ values for all other pairs of variables were found to be $<0.2$.

Given the quality of the effluent was found to be generally suitable for agricultural irrigation, the second step of the study involved the investigation of farmers' perception of this practice. The majority of the farmers (7 out of 11) were between 41 and 60 years, and they were all males. Five respondents matriculated or had lower education. The remaining six respondents attained a tertiary educational qualification and two of them have an agriculture-related diploma or degree. The smallest farm size was 8 ha, and the largest 192 ha. Six farms were $<50$ ha, three farms were between 50 and 100 ha, whilst two farms were 172 ha and 192 ha. The finding was that bigger farms irrigate larger areas, so they need more irrigation water to meet the demand. Big farms are therefore more likely to adopt an unconventional water source such as treated effluent compared to small farms. 


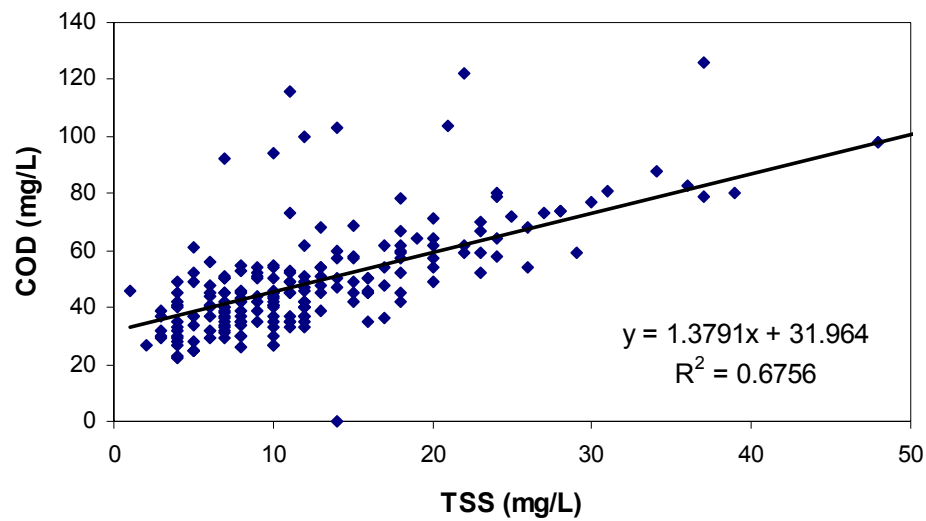

Figure 2: Regression analysis between chemical oxygen demand (COD) and total suspended solids (TSS) in effluent from the Scottsdene wastewater treatment works.

The main crops grown by the respondents in the Bottelary catchment were beans (6 farmers), carrot, cabbage and cauliflower (5), grapes (4), potato and lettuce (3), chilli, pumpkin, pepper, radish and beetroot (2), and grasses (1). Some farmers grow more than one crop. According to the data of crop salt tolerance published by Maas [10], the most popular crops amongst the respondents (beans and carrot) are sensitive to salinity. Cabbage and cauliflower were also widely grown in the study area and they are moderately sensitive to salinity. The average EC of the Scottsdene WWTW final effluent was 50 $\mathrm{mS} \mathrm{m}^{-1}$. This saline water gets more concentrated in the soil solution due to crop water uptake and it may affect crop yield, although no dramatic yield reduction can be expected, provided appropriate irrigation scheduling is practiced. Some of the salts are expected to be washed out of the root zone through rainfall, in particular during the rainy winter season. It should be noted that, due to high investment and management costs in vineyards, high quality effluent needs to be guaranteed and specific management practices need to be ensured on vine farms in order to avoid losses of profit that could be extremely detrimental to the business. Based on the questionnaire, all farmers used sprinkler irrigation systems (11). Other irrigation methods adopted were drippers (4 farmers), microjets (2) and subsurface irrigation (1). Some farmers used more than one irrigation method. If the effluent quality is poor, sprinkler irrigation can cause potential hazards to farm workers, crop leaves and soil. The main negative impact of effluent irrigation with drip systems is the clogging of emitters.

Eight respondents agreed that there is a water shortage problem in the area. All vineyard farmers strongly supported this point. Three respondents, who have small size farms, did not agree that there is a water shortage problem. Six respondents were using treated effluent for irrigation. These were mainly 
vegetable farmers, whilst no vineyard farmer used treated effluent. Six respondents were willing to increase the area irrigated with treated effluent, whilst the remaining five preferred fresh or other waters. Compared to other water sources, the treated effluent has a relative cost advantage to the farmers.

All respondents pointed out that the absence of infrastructure, such as the lack of pumping facility for conveying water to the farm land or no pipe connecting treated effluent to the users is one of the reasons for not practicing effluent irrigation. The respondents who did not adopt effluent irrigation were concerned that the poor quality water may harm the soil, reduce crop yields as well as impact negatively on human health and the environment. One respondent stated that "considering the consumers' interest" was the second reason why he used fresh water irrigation. However, all respondents who did not use treated effluent were willing to accept it, but with caution. Concerning the effluent irrigators, four out of the six respondents showed no concern. The other two respondents were concerned that effluent irrigation may bear health hazards.

Based on the promising feedback from the first two stages of the study (effluent quality and farmers' perception), it was considered that the area irrigated with treated effluent could potentially be increased to a large scale. The first step of the procedure for estimation of the potential area that can be irrigated involved the selection of a representative cropping system. Based on the questionnaire survey, a generic cropping system including winter and summer vegetables was selected in SAPWAT. Planting dates of crops were 1 October for summer-planted vegetables and 1 March for winter-planted vegetables. The crop canopy cover at full growth was selected to be $90 \%$, and the wetting frequency was seven days throughout the season, based on common practices in the area. The wetted area was $100 \%$, representing sprinkler irrigation with an application efficiency of $85 \%$. Based on these inputs, the SAPWAT model was used to calculate monthly irrigation requirements (table 2).

For summer-planted vegetables, the default growth season was from October to February. The total seasonal water requirement was the sum of the five months' irrigation requirements, namely $684 \mathrm{~mm}$. The total effluent flow was $1,120 \mathrm{ML}$ (the sum of the five months' average effluent flow). By dividing the total available effluent flow by the total irrigation requirement for this period, the total potential area that could be irrigated with treated effluent for summer planted vegetables was calculated to be 164 ha. The potential extent of effluent irrigation of summer-planted vegetables was smaller than the total farming area of effluent users in the surveyed group (213 ha). This indicates that the volume of effluent available may not be enough to satisfy crop water requirements, should the current effluent users want to irrigate the whole area of their farms. As the treated effluent in summer makes up the entire river flow, this means that there is potential to dry out the Bottelary river in summer, should an extended area be irrigated.

For winter-planted vegetables, the growth season is from March to August. The total irrigation requirement was the sum of the irrigation requirements from March to May, namely $154 \mathrm{~mm}$. During June, July and August, no irrigation requirements were calculated as rainfall is expected to fully satisfy crop water 
requirements. The total effluent flow from March to May was 760 ML. Effluent could be stored during periods of no irrigation requirements, or when the effluent flow is higher than the irrigation requirements. This stored effluent could then be used during the months of peak irrigation requirements. Storage reservoirs could also act as maturation ponds and buffer the effluent quality. In table 2 , the balance between the surplus effluent in winter and the surplus demand in summer was determined for generic vegetables irrigated with a sprinkler irrigation system. Assuming full storage of effluent from March to May, it was calculated that the potential area that could be irrigated is 224.5 ha. A storage capacity of $315.13 \mathrm{ML}$ would be required under these conditions. The storage facility would be filled with water in October (table 2), before the start of the summer season. The period of no irrigation requirements for this cropping system (June, July and August) was not included in the calculation, as there is currently no capacity or area to store such volumes of effluent.

It should be noted that water losses accounted for in the SAPWAT model are related only to the efficiency of the irrigation system, and do not include losses due to evaporation and seepage from storage facilities, conveyance losses etc. These additional losses would further decrease the efficiency of the system resulting in smaller areas that could potentially be irrigated.

Table 2: The balance of excess winter effluent flow and excess summer effluent demand for generic vegetables irrigated with a sprinkler irrigation system.

\begin{tabular}{|c|c|c|c|c|c|}
\hline Month & $\begin{array}{c}\text { Effluent flow } \\
\text { (EF) } \\
\text { (ML/month) }\end{array}$ & $\begin{array}{c}\text { Irrigation } \\
\text { requirements } \\
(\mathrm{mm} / \mathrm{month})\end{array}$ & $\begin{array}{c}\text { Effluent } \\
\text { requirement } \\
(\mathrm{ER}) \\
\text { (ML/month) }\end{array}$ & $\begin{array}{c}\text { Cumulative } \\
\text { difference } \\
\text { between ER } \\
\text { and EF (ML) }\end{array}$ & $\begin{array}{c}\text { Area } \\
\text { (ha) }\end{array}$ \\
\hline January & 279 & 211 & 473.70 & 194.70 & \multirow{8}{*}{224.5} \\
\hline February & 190 & 109 & 244.71 & 249.40 & \\
\hline March & 217 & 69 & 154.91 & 187.31 & \\
\hline April & 252 & 62 & 139.19 & 74.50 & \\
\hline May & 291 & 23 & 51.64 & -164.87 & \\
\hline October & 267 & 52 & 116.74 & -315.13 & \\
\hline November & 183 & 92 & 206.54 & -291.59 & \\
\hline December & 202 & 220 & 493.90 & 0.31 & \\
\hline
\end{tabular}

\section{Conclusions}

The reuse of treated effluent for agricultural irrigation can release pressure on fresh water resources and holds a promising future. However, the indiscriminate use of treated wastewater for irrigation could cause the problems associated with sewage reuse to merely shift from surface waters to soils, vegetation and groundwater, or from one water user to another. Also, the impact of this practice on the environment could take a long time to manifest and regular monitoring is essential. Socio-economic factors also play an important role in the implementation of this technology. Education, information and training of 
farmers are essential for operations with effluent irrigation. The infrastructure for effluent irrigation of a broader area could be planned. Farmers' involvement is important in this process. The building of storage dams is also needed in order to balance the effluent demand and supply. The findings of this study could be useful to other regions that have similar problems of water shortage and treated effluent production.

\section{Acknowledgements}

The author wishes to acknowledge the contributions of Ms Li Rui (MSc student at the Department of Earth Sciences, University of the Western Cape), Mr Alfred Mbewe (City of Cape Town) who provided water quality data, Prof Lincoln Raitt (Department of Biodiversity and Conservation Biology, University of the Western Cape) for his valuable inputs during questionnaire distribution and collection, Mr Charles Crosby for his assistance in the use of the SAPWAT software, as well as the farmers in the study area for their collaboration.

\section{References}

[1] Pescod, M.B., Wastewater Treatment and Use in Agriculture, FAO Irrigation and Drainage Bulletin No. 47, FAO: Rome, Italy, 1992.

[2] United Nations Environment Programme (UNEP), Source Book of Alternative Technologies for Freshwater Augmentation in Latin America and the Caribbean. International Environmental Technology Centre, United Nations Environment Programme: Osaka/Shiga, Japan, 1997.

[3] Angelakis, A.N. \& Bontoux, L., Wastewater reclamation and reuse in Eureau countries. Water Policy, 3(1), pp. 47-59, 2001.

[4] Toze, S., Reuse of effluent water - benefits and risks. Agricultural Water Management, 80(1-3), pp.147-159, 2006.

[5] United States Environmental Protection Agency (USEPA), Manual Guidelines for Water Reuse, EPA/625/R-92/004, Environmental Protection Agency: Washington, D.C., U.S., 245 pp., 1992.

[6] World Health Organization (WHO), WHO Guidelines for the Safe Use of Wastewater, Excreta and Greywater, ISBN 924154683 2, World Health Organization: Geneva, Switzerland, 2006.

[7] Crosby, C.T., SAPWAT 1.0 - A Computer Program for Estimating Irrigation Requirements in Southern Africa, Report No. 379/1/96, Water Research Commission: Pretoria, South Africa, 1996.

[8] Ayers, R.S. \& Westcot, D.W., Water Quality for Agriculture, FAO Irrigation and Drainage Paper No. 29, Food and Agriculture Organization of the United Nations: Rome, Italy, 1985.

[9] Department of Water Affairs and Forestry, South African Water Quality Guidelines. Volume 4: Agricultural Water Use, Department of Water Affairs and Forestry, 2nd ed.: Pretoria, South Africa, 1996.

[10] Maas, E.V., Salt tolerance of plants. Applied Agricultural Research, 1(1), pp. 12-26, 1986. 